\title{
UNEVEN EUFICATION, THE SPATIAL FIX AND THE DOMINANCE OF ECONOMIC OVER SOCIAL POLICIES
}

\author{
ENIKŐ VINCZE1
}

\begin{abstract}
I am proposing to use the term EUfication to define the process of creating the EU as territory out of the geographical disparities (re)produced across the core and periphery of Europe. The article contends that EUfication is a manifestation of the phenomenon of spatial fix. In a first step, it describes the dynamics of territorial unevenness within the EU: on the one hand, by some relevant socio-economic cohesion data compiled from Eurostat indicators, and - on the other hand - through the diagnosis on spatial injustice in different Member States, as it was revealed by a comparative research conducted between 2017-2019. Furthermore, my analysis explains territorial unevenness by reconstructing the well-known historical formation of the union through a less acknowledged perspective, i.e., in the context of the changing regimes of capital accumulation. The article concludes that the theory of spatial fix allows us recognizing: the position and timing, from which and when different countries took part in the process of EUfication is a factor leading to the persistence of uneven territorial development among the European core and periphery. My contribution to theorizing on this process consists in bringing together the perspective of the spatial fix with the critical analysis of how is the social dimension paradigm overshadowed by the economic concern of capital accumulation in the socio-economic governance of the European Single Market, including the politics of territorial cohesion.
\end{abstract}

Key words: spatial fix, uneven EUfication, capital accumulation, uneven development

\section{Introduction}

According to the thematic Green Paper of the European Commission (2008), territorial cohesion is a condition that "ensures a balanced and sustainable territorial development of the EU as a whole, strengthening its economic competitiveness and capacity for growth while respecting the need to preserve its natural assets and ensuring social cohesion (Medeiros, 2016: 8)." My paper

1 Babeș-Bolyai University, eniko.vincze10@gmail.com. 
aims to have a contribution to the understanding of why, despite such a spatial policy, the EU is characterized by territorial unevenness. For this, I am employing the critical perspective on uneven development (Smith, 1984; Harvey 2005, 2006) and on the spatial fix (Harvey, 2001; Jessop, 2004) as endemic features of capitalism, and as well as on how the economic policies of the EU hindered its social dimension even within the frame of cohesion policy (Marlier et al., 2010; Lang and Görmar, 2019; Vanhercke et al., 2020).

Right after this introduction, the first section of the article outlines the theoretical frames of my analysis. The second section addresses some issues, through which the phenomenon of territorial unevenness might be exposed. For this reason, on the one hand, it appeals to Eurostat data on economic and social cohesion for 11 selected countries: GDP per capita, unemployment rate, income inequality, poverty, social exclusion, and governmental expenditure on social protection. On the other hand, to uncover how neoliberal governance impacts unevenness regardless of the type of administrative-territorial organization of different countries, the analysis makes use of the national reports of RELOCAL research conducted on spatial injustice. ${ }^{2}$ The selection of the countries for the statistical comparisons was based on the list of countries covered by these reports, which at its turn carefully combined different welfare regimes and European geographies across North-South and West-East.

After displaying the realities of unevenness across countries, the third section of the article focuses on the understanding of the causes of enduring uneven development in the EU. In this endeavor, I am informed by some critical analysis about divisive integration, Eastern enlargement, and the EU as an empire (Böröcz and Kovács, 2001; Zielonka, 2006; Lehndorff, 2015; Behr and Stivachtis, 2016; Schmidt, 2018; Vincze, 2019). But most importantly, I am relying on a historical and political economy perspective. This enables me to reconstruct from what position and when did the different Member States contribute to the creation of the union as a new territory or the EUfication of dispersed geographies. It will be shown that this process began with the creation of an economic community, which - despite enlarging the policy sectors that entered into its interest over time - remained predominantly an economic creation. As a Single Market, since its existence, the EU has elaborated and adopted compulsory economic, fiscal, and monetary policies across the Member States, while on the domain of social policies it limited itself to some recommendations and exchange of good or bad practices among the country leaders.

2 RELOCAL. Resituating the Local in Cohesion and Territorial Development (2017-2021) is a research based on 33 case studies conducted in 11 countries in local contexts. This investigation understands spatial injustice as "an equitable spatial distribution of resources and opportunities, and fairness in the relations of power that shape and transform the social space" (Madanipour et al., 2017: 74). 
The article concludes that the spatial fix underlying the process of EUfication, alongside the structural tension between the economic and social policies practiced by the European Union, are the explanatory factors of unevenness in the competition union that persists despite the EU's territorial cohesion policy that eventually reproduces the predominance of the Single Market's concerns over the social dimension of Europe.

\section{Theoretical frames for understanding spatial fix and policies}

The theory of uneven development (Smith 1984; Harvey 2005, 2006) helps us to critically reveal that the territorial unevenness across the European Union is an endemic feature of capitalism and that a policy - which has to strictly respect the major rules of the Single Market - cannot assure the dreamt balanced development of its Member States and regions. Very simply put: to reproduce itself, capitalism needs and creates uneven development, and the free movement of capital and free trade across borders or territories are political inventions supporting capital accumulation. Viewing the EU as an illustration of how capitalism was restructured geographically after the second world war, or as an example of a shift in the geographical scale at which capitalism is organized, supported by a specific supra-state organizational form, David Harvey (2001) might assist us in this endeavor. Uneven development is a macro-force of capitalism related to the logic of capital investment and accumulation supported by state politics. It is a systematic product and geographical premise of capitalist development: a landscape of developed and less developed spaces of different scales, but also the ground of further capitalist expansion, meaning that uneven development is exploited by capital for further accumulation (Smith, 1984). Differently put, uneven development is an endemic feature of capitalism (Harvey, 2005; 2006) because capitalism depends on the capacity to expand towards territories, sectors, and domains not yet incorporated into the circulation of capital. Capitalism is addicted to geographical extension, says Harvey, i.e., to spatial fix, by the means of which it resolves its inner crisis tendencies in one territory via geographical expansion and geographical restructuring (Harvey, 2001: 24).

Practitioners of policies and policy-makers themselves understand policies as technical solutions to problems supposedly existing out there in themselves. This standpoint is critically addressed by the sociology and anthropology of policy that emphasized why and how policies are not neutral instruments, but tools of political technology and power, informed by dominant ideologies, creating both "the problems" and the acting subjects via governmentality (Shore and Wright, 1997, 2011). Since policies work as instruments of political intervention, they express the interests that politicians consider worth supporting while governing the city, the state, the EU. As will be shown later in the article, 
during the EUfication process - viewed in the context of changing regimes of capital accumulation - economic policies sustaining the Single Market supported the interests of the capital and they prevailed over the social policies. Supposedly, the latter was invented to counter-balance the inequalities produced by the predominant profit-oriented economic policies, but they are not assumed as compulsory EU policies and at the best are externalized to project-based initiatives, and most importantly they do not act on the structural causes of inequalities.

The theory of spatial fix explaining capital accumulation through territorial expansion and the theory of policies as instruments of power, enable me to consider that the need for new territories for capital accumulation as an engine of EUfication led to the creation of possibilities for the free movement of capital, while it relied on the dominance of economic policies over the social ones in the EU as territory. Together, spatial fix serving capital accumulation and the subordination of the social to the economic, are political economy mechanisms that (re)produce territorial unevenness across the EU.

\section{The realities of unevenness in the EU}

While territorial cohesion is a political option of the EU for a balanced development across territories, spatial unevenness is a reality created by capitalist political economy, so not only by economic unbalances of turbulent times, but also by long-duré neoliberal governance. To describe this state of facts, I am appealing to the already mentioned RELOCAL research. The studied cases represented local situations from different welfare regimes, different types of actions conceived to address diverse forms of spatial injustice, a large palette of top-down and bottom-up actions, diverse territorial governance arrangements, all of these displayed in localities that ranged from small areas, such as a group of villages or urban neighborhoods to larger regions. ${ }^{3}$ I have decided to extract from the rich data-sets of RELOCAL some conclusions of the National Reports 4 published on the project's website, which are relevant for the topic of my article. But before doing that, as the first step in this section, I am offering a brief overview, through Eurostat indicators of economic and social cohesion, on the endurance of territorial inequalities in the EU, in particular across the selected 11 countries.

3 Research Institute for Regional and Urban Development (ILS): Situating the RELOCAL Cases. Cross-Comparative Analysis of Country Perspectives on Spatial Justice, Deliverable 6.4 of the project, https://relocal.eu/deliverables/

4 The ten contextual reports to which I am referring to in my paper (Germany, France, Netherlands, United Kingdom, Spain, Greece, Sweden, Hungary, Poland, Romania), are available on the RELOCAL website - https://relocal.eu/all-cases-2/. 


\section{Persistent socio-economic unevenness revealed by statistics}

The list of the indicators used to measure the state of socio-economic cohesion in the EU is very extensive (Medeiros, 2016, pp. 13-14). What I am offering here is only a small window through which one may have a look at some general trends of unevenness between the European core and periphery countries.

Figure 1. Population change in the RELOCAL countries selected years between 1990-2019

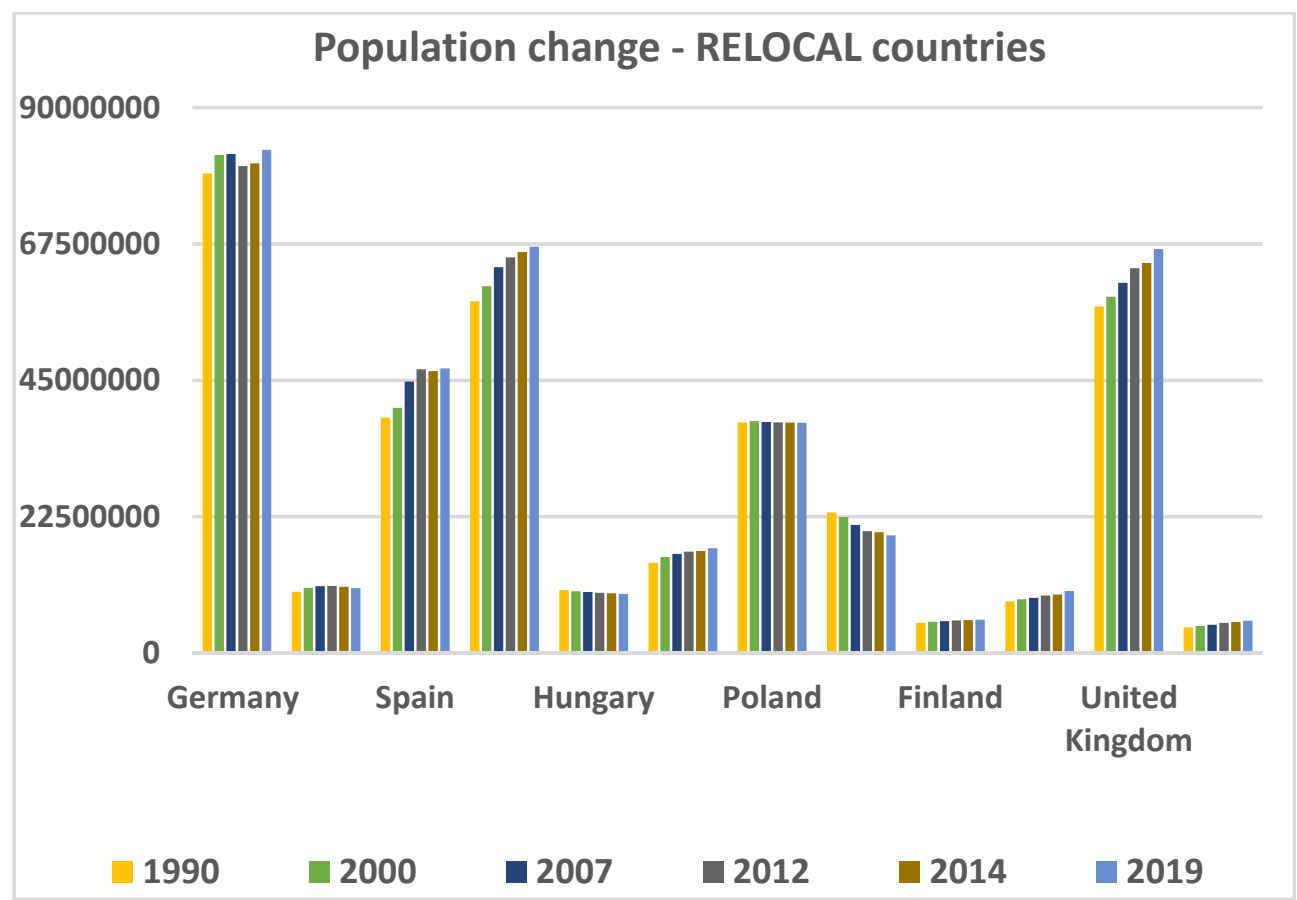

Source: Eurostat data ${ }^{5}$ processed by the author

One of the issues recognized by the EU decision-makers as a major fact reflecting spatial unevenness is related to the demographic imbalances across territories at different scales, i.e., to how are some territories depopulating while others become overcrowded. As Figure 1 shows, the population number

5 http://appsso.eurostat.ec.europa.eu/nui/show.do?dataset=demo_gind 
evolved differently between 1990-2019 in the selected countries: in Romania decreased, in Hungary, Poland and Greece stagnated, and in the rest went through an increase to a higher or smaller degree.

At their turn, depopulation or over-crowdedness are also structural reactions to the changing trends of concentration of economic activities in some territories. Due to the latter, the capital cities (and some major second-tier cities) are placed in advantageous positions in the competition for developmental resources, as Figure 2 reflects.

Figure 2. The most competitive regions in Europe

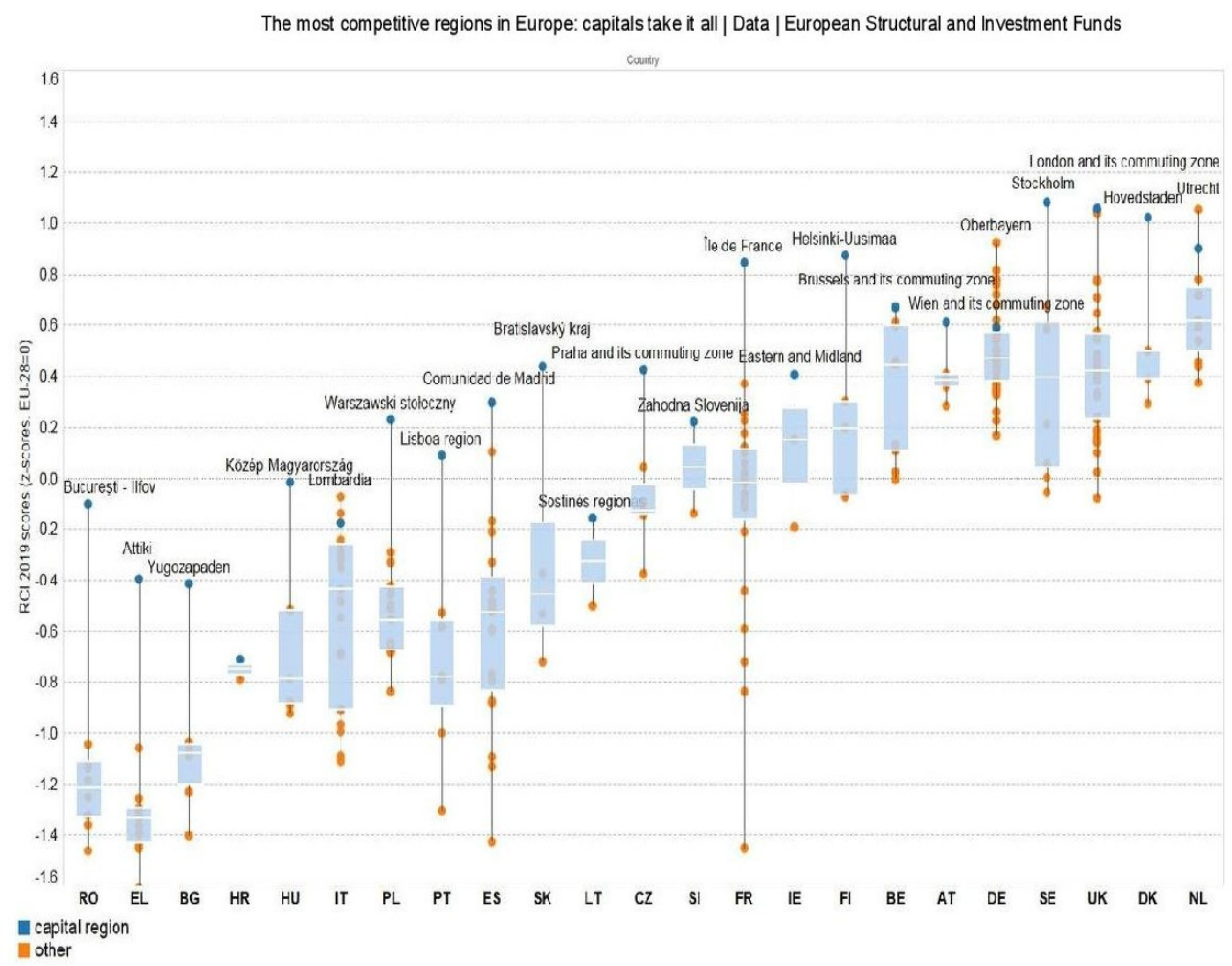

Source: https://cohesiondata.ec.europa.eu/stories/s/yt77-f74u

Further on, the country-specific data on GDP per capita, which is used in the EU as an indicator of economic cohesion, reflects the big discrepancies between the selected countries (Figure 3). 
Figure 3. The evolution of the real GDP per capita in the RELOCAL countries, 2002-2019

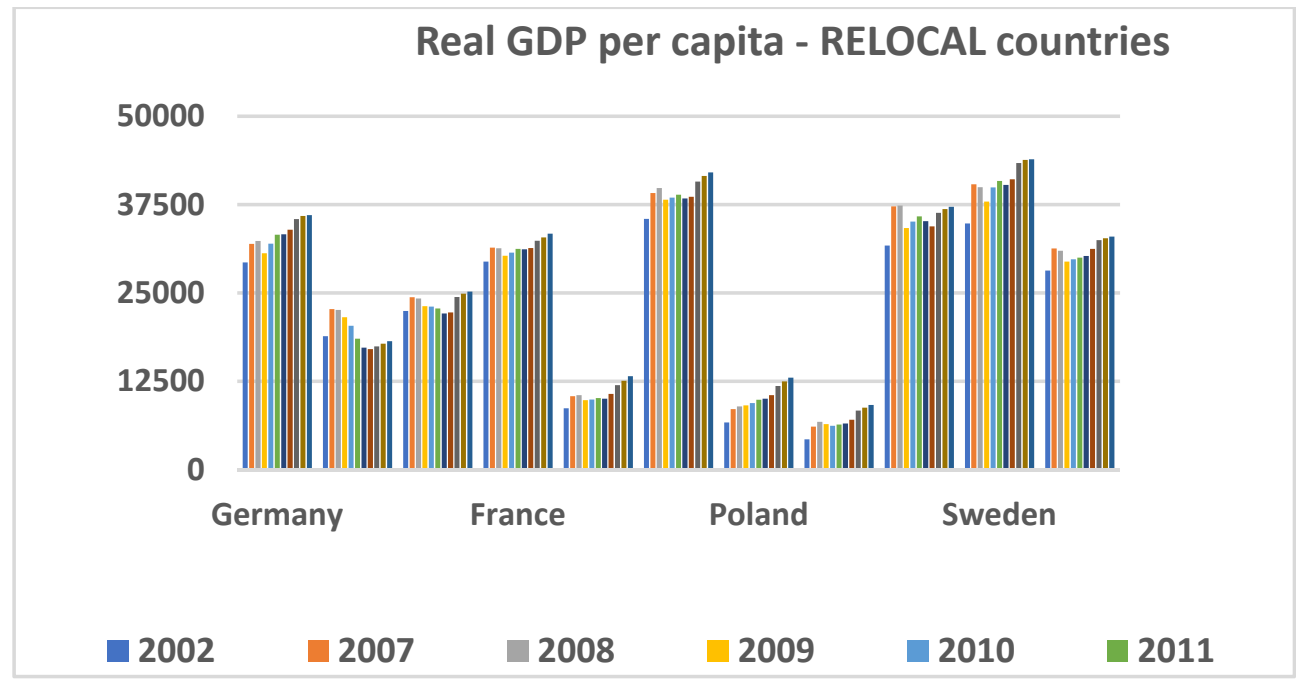

Source: Eurostat, ${ }^{6}$ data extracted and processed by the author

Besides the indicators mentioned above, the unemployment rate is also used as a sign of uneven development. Figure 4 situates the selected countries on the waves of increasing-decreasing unemployment. These numbers, however, might induce some wrong conclusions regarding, for example, the relatively low unemployment rate in Romania. The latter is not owed to an effervescent economic activity across the country, but - even if some major cities slowly recovered from the economic recession of the 1990s and the 2008-2009 financial crisis - the low unemployment rate is mostly due to the very large number of Romanian citizens engaged in labor-migration towards other EU countries or other states. Nevertheless, Figure 4 reflects that while the unemployment rate for the total population aged 15-74 decreased between 2005 and 2019 by 2.9 percentage points in the EU-27, from $9.6 \%$ to $6.7 \%$, twenty EU Member States recorded lower, while others displayed increased unemployment rate in this period. Referring to the selected countries, the decrease was largest in Poland (14.5 p.p.), followed by Germany (8.0 p.p.), while, on the other side, the largest increases happened in Greece (7.3 p.p.) and Spain (4.9 p.p.).

6 https://ec.europa.eu/eurostat/web/products-datasets/-/sdg_08_10 
Figure 4. The unemployment rate in selected countries

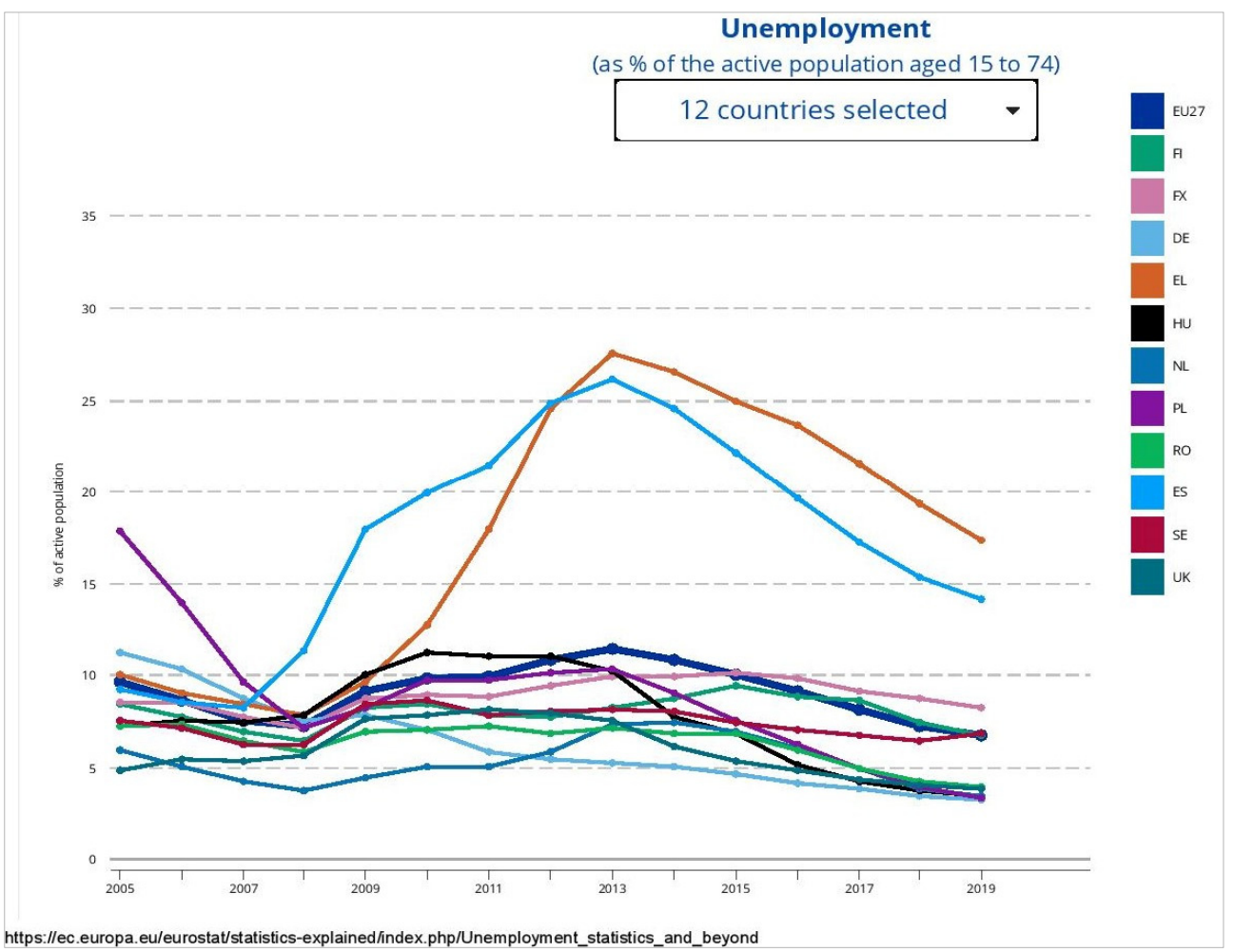

Source: Eurostat data, ${ }^{7}$ processed by an interactive line chart

Moreover, the following Figures reflect the persistent unevenness between the EU Members States, in particular between the selected countries in what regards social inequalities, measured by social cohesion indicators such as: at risk of poverty thresholds (Figure 5), in-work at risk of poverty rate (Figure 6), income disparities (Figure 7), and governmental expenditures on social protection (Figure 8). If one picks up the example of Romania from this picture, they may observe how striking is that, while this country knows the highest poverty rates and income inequalities, it has the lowest percentages regarding the amount of public budget spent on social protection. This is how Romania is kept in the status of a semi-periphery country with the cheapest labor force in the EU, fulfilling in this way one of its major roles in the global economy.

7 https://ec.europa.eu/eurostat/statistics-explained/index.php/Unemployment_statistics_ and_beyond\#How_has_unemployment_evolved_in_the_last_15_years_.3F 
Figure 5. At-risk-of poverty thresholds in selected countries and years, between 2007-2019

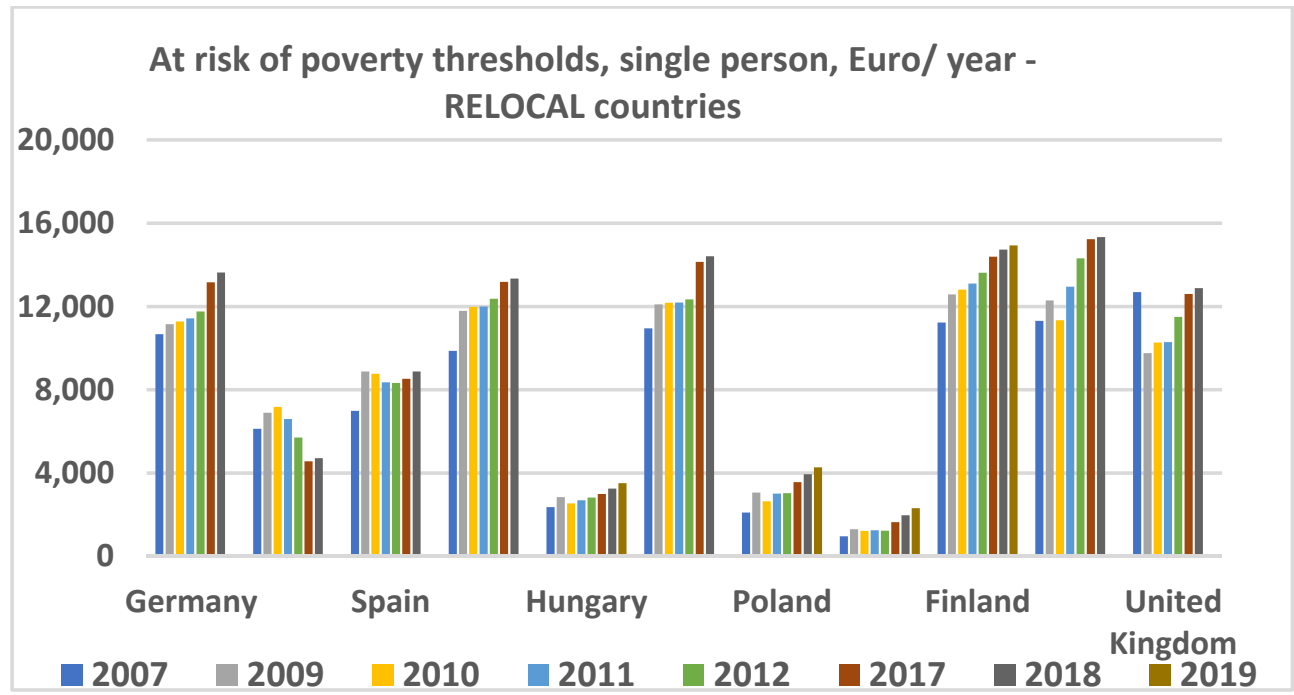

Source: Eurostat data, ${ }^{8}$ processed by the author

Figure 6. In-work-at-risk of poverty rate in selected countries and years, between 2008-2019

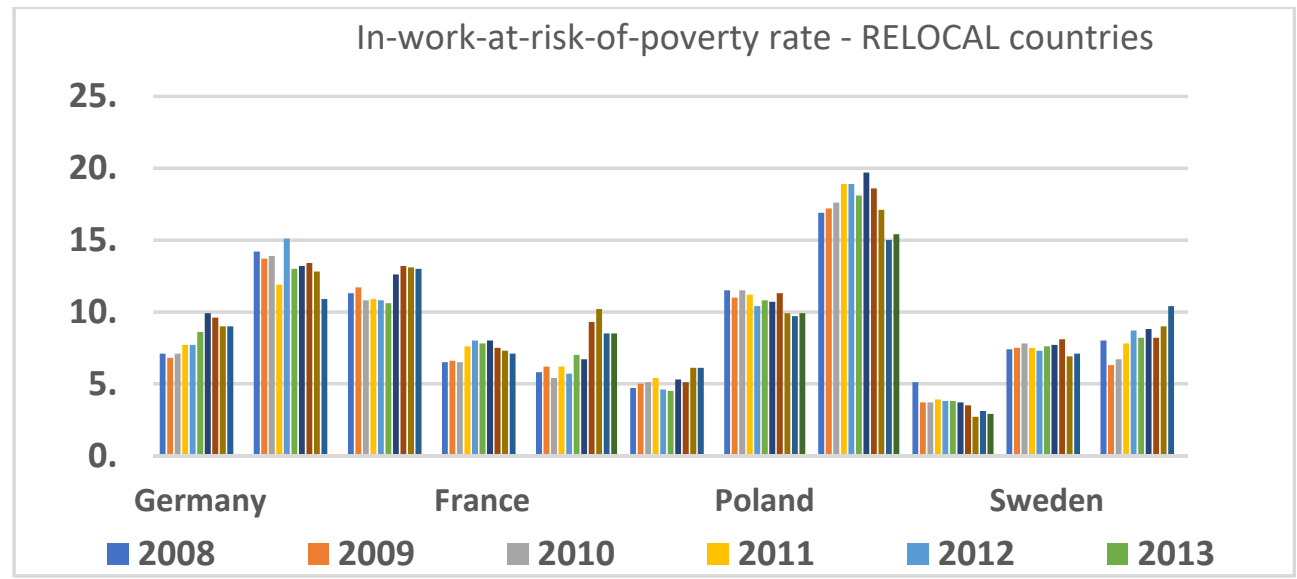

Source: Eurostat data, ${ }^{9}$ processed by the author

8 http://appsso.eurostat.ec.europa.eu/nui/show.do?dataset=ilc_li01\&lang=en

9 https://ec.europa.eu/eurostat/tgm/table.do?tab=table\&init=1\&language=en\&pcode= tespm070\&plugin $=1$ 
Figure 7. Income inequality in selected countries and years, between 2011-2019

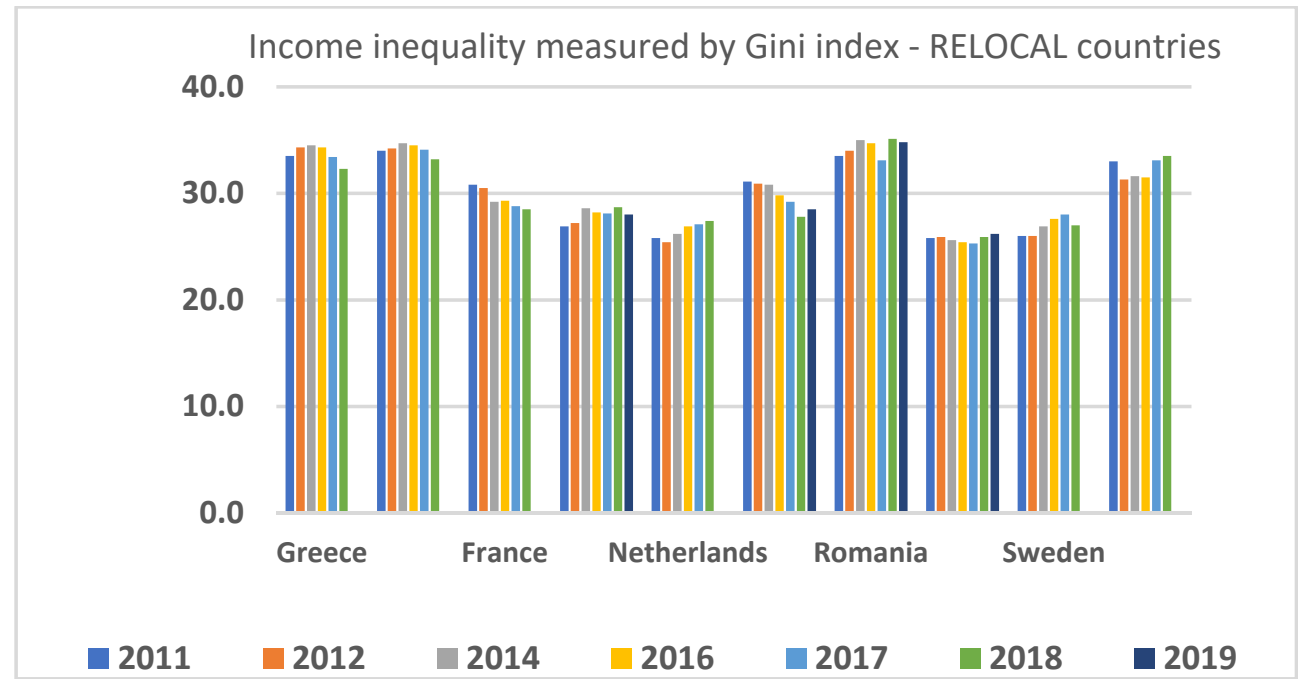

Source: Eurostat data, ${ }^{10}$ processed by the author

Figure 8. Percentage of GDP spent on social protection in selected countries and years, between 2007-2019

Percentage of GDP spent by the government on social

32.5 protection - RELOCAL countries

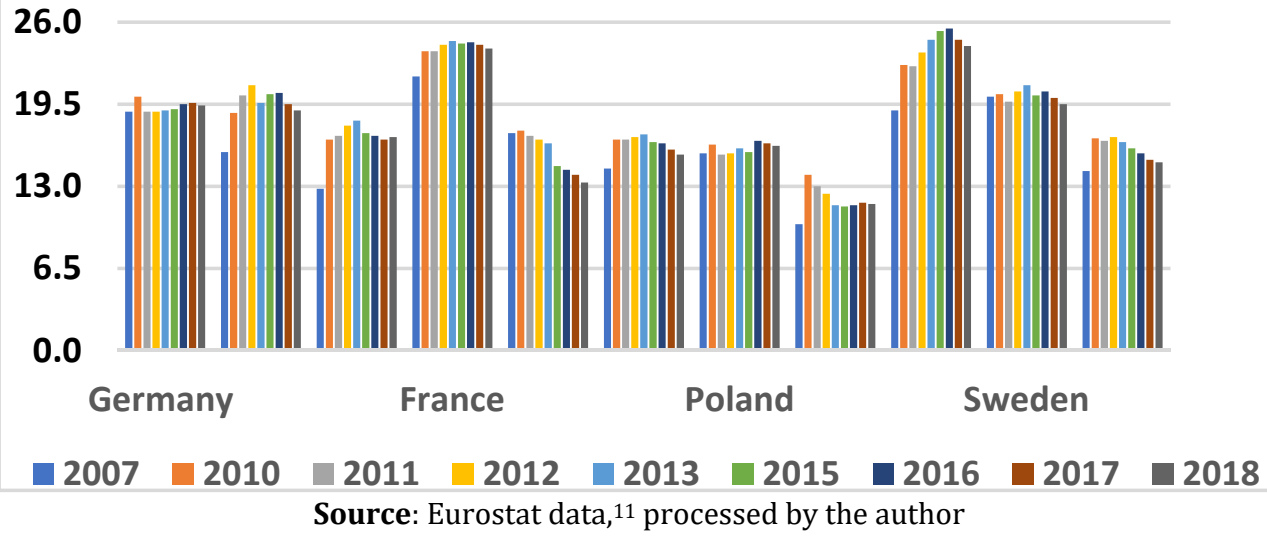

10 http://appsso.eurostat.ec.europa.eu/nui/show.do?lang=en\&dataset=ilc_di12

11 https://appsso.eurostat.ec.europa.eu/nui/submitViewTableAction.do 


\section{The production of unevenness across different forms of administrative-territorial organization through neoliberal governance}

Since the Barca Report (2009), the EU's Cohesion Policy aimed to reform itself via adopting the territorial perspective and the place-based development approach, which proposed geographically tailored interventions in functional territorial units. But even before this moment, the approval of the European Spatial Planning Perspective (1999) meant that the Member States and the European Commission committed themselves to the idea, according to which three fundamental goals should be achieved equally in all the regions of the EU: economic and social cohesion; conservation and management of natural resources and the cultural heritage; more balanced competitiveness of the European territory. Further on, the first version of the Territorial Agenda of the European Union was agreed in 2007 by the Ministers responsible for spatial planning and development.

Despite its success story, the concept of territorial cohesion does not have a widely accepted definition nor in the EU documents or academic literature. Going beyond this recognition, some analysts are proposing complex understandings of the concept, which besides the socio-economic dimensions includes other aspects, too, such as environmental sustainability, territorial polycentricity, territorial cooperation, and territorial governance dimension (Medeiros, 2016, pp. 10-19). After focusing in the prior section of the article on the first dimension of territorial unevenness via statistics, in what follows - on the base of some selected RELOCAL National Reports -, I will discuss how neoliberal governance functions in different countries with different types of administrative-territorial organization and how it reproduces similar patterns of in-country inequalities manifested in space.

From the category of core European countries, I have selected for this analysis Germany and France (creators of the first European economic community), the United Kingdom (joining the former in 1973), and Sweden (a latecomer core country, accessing the EU in 1995); and from the Southern and Eastern peripheries, Spain (accessing European communities in the 1980s) and Romania (latecomer MS from 2007). Out of them, France, Sweden, and Romania do have in common that they are defined as unitary states going through a recent process of decentralization, while Germany, the UK, and Spain display a longer history of decentralized administrative-territorial governance.

First, let me recall that rising unemployment rates, persisting long-term unemployment, weak economic infrastructure, low incomes, shrinking cities, and rural areas as a result of de-industrialization and the outmigration of the youth, are issues occurring all over in the countries where the RELOCAL research 
was conducted. Meanwhile, government representatives, national, regional, or local, did not consider using the term spatial injustice to uncover inequalities, but they mostly preferred discussing disparities and continued to express an official optimism about the great potential of the EU Funds in tackling them. Nevertheless, as the investigation exposed, people from the deprived or underdeveloped territories and the grassroots-action stakeholders shared a strong sense of injustice expressed through the feeling of being left behind by their states and/or by Europe.

Federalist Germany, still sustaining a state-based welfare regime or social state, even if weaker than decades before, as the EU country with the best economic indicators and the largest number of multinationals conquering the economies of the European periphery, displays disparities among its Western and Eastern, and its Northern and Southern territories. We could learn from the RELOCAL case studies how were its remote country-sides looking for innovative connections to the world (through digitalization), and how did the youth from cities going through depopulation try to reinvent local community life through cultural events. The authors of the National Report ${ }^{12}$ consider that - under conditions in which recently one may observe a shift of responsibilities to the local level - the German social state should not be eroded and should remain accountable for structural inequalities and territorial disparities. Besides - while appreciating what a social city might do - they consider that it would be good to integrate successful civil initiatives to higher-level structures, nevertheless, it would be also necessary that dispersed grass-roots projects would be coordinated by an overhead structure in public administration.

The centralized republic of France, in the past decades of neoliberalism, underwent successive waves of decentralization. Meanwhile, the French ideal of equality did not disappear from the public sphere, but it knew several transformations. The century-old principle of l'egalite des territories, which recognized the value of each space due to their specific contribution to the economy as a whole, under conditions of decentralization and de-industrialization is transformed into the idea of competitive regulation of territorial cooperation. The new role of the state in this context is to launch nationally led thematic initiatives to support local development and to provide related financial schemes. The analyzed French cases displayed top-down and bottom-up initiatives. One of them was more focused on improving procedural justice in the metropolitan government, and the other implemented a housing project in a severely declined

\footnotetext{
12 https://relocal.eu/wp-content/uploads/sites/8/2019/09/RELOCAL-National-Report_Germany.pdf
} 
region. The authors of the National Report ${ }^{13}$ ask if greater autonomy assures or not greater spatial justice. They conclude that under conditions in which the deepened territorial inequalities require committed governmental redistributive measures and the real access of those in need to EU regional policy tools and resources is reduced, the French state should plan and coordinate more topdown appropriate measures, even if bottom-up case-sensitive local projects should also continue to be supported from the public budget.

The centralized governmental regime of the United Kingdom started to go through devolution in the 1970s, so the analyzed RELOCAL cases in Scotland and England already were actions affected by the particularities of different national contexts. Nevertheless, after the 2008-2009 crisis, the central government of the UK disbanded the regional levels of government and promoted the distribution of EU funds towards initiatives with a strong business focus. The authors of the National Report ${ }^{14}$ note that beyond these changing trends, it is the neoliberal welfare regime and austerity-led reduction in the public sector, which created a huge need in both territories to tackle - via project-based interventions - structural spatial problems. Therefore, the analyzed English local action aimed to stop homelessness under conditions of high rents, insecure tenancies, and insufficient social housing. While the Scottish initiative created a community land trust to empower low-income people from disadvantaged areas.

With a strong central government, Sweden displays a society-based welfare regime informed by the value of equality, which has been mostly under social democratic leadership since the second World War. Nevertheless, in the past three decades, large inequalities have grown in Sweden due to neoliberal policies applied after the financial crisis in the late 1980s. In what regards the country's administrative-territorial organization, its 290 municipalities enjoy considerable autonomy, however regional authorities are granted rather limited responsibilities. One of the cases studied by the RELOCAL research was about how increasing access to digital services of citizens, companies, and tourists was considered to have a contribution to the reduction of territorial disparities. The other initiative was more of a socially committed endeavor from the side of city authorities to increase social sustainability understood as the fair distribution of life conditions and well-being among all people. Recently, the Swedish multi-level system of governance is undergoing major changes.

\footnotetext{
13 https://relocal.eu/wp-content/uploads/sites/8/2019/11/RELOCAL-National-Report_ France.pdf

14 https://relocal.eu/wp-content/uploads/sites/8/2019/10/RELOCAL-National-Report_ Scotland-and-England-CHECKED-FINAL.pdf
} 
City districts are transformed into "Regions," and gain responsibilities for regional development, which earlier was a state responsibility carried out via the Counties. The authors of the National Report ${ }^{15}$ consider that, since this measure took place only in 2019 , it is too early to evaluate the impact of this wave of decentralization on spatial (in)justice.

Since 1978, Spain is divided into seventeen autonomous communities and two autonomous cities as a way to recognize the right to self-government of the "nationalities and regions." The autonomous communities have wide legislative and executive autonomy which is acted out through their parliaments and regional governments. The authors of the National Report ${ }^{16}$ observe that urban growth happening in Spain between 1960-1975 created several disadvantaged neighborhoods, which were under-urbanized, poorly communicating with the rest of the locality, suffered from an infrastructure deficit, and were socio-spatially segregated. In time, many of these neighborhoods became more and more abandoned and marginalized, and these disadvantages were only partially overcome by people's struggle for the improvement of their conditions. From 1990, the local administrations, pushed by civil society pressure, started to improve the infrastructure and services mostly in declined rural areas to increase the opportunities for regional development. Nevertheless, what has happened ever since, does not seem to be enough, and the targeted rural areas continue to decrease in the number of inhabitants year after year, which at its turn triggers an increase of territorial inequalities across all the autonomous communities. In what regards urban areas, experts agree that one of the most important policy domains to focus on should be housing because difficult access to housing is one of the key factors leading to the increase of social inequality in present days Spain. Housing is also the target of civil society organizations. "Sindicat de Llogaters" in Barcelona fights for fair rents in the city; "Santa Coloma - Renovem els barris" is a project to improve housing stock in a street in the Metropolitan Region of Barcelona; "Habitatges en cessió d'ús" is a project through which the Barcelona City Council facilitates the access to land to be used for housing cooperatives; and "Fundació Hàbitat 3" is a private foundation that manages housing to support social inclusion in Barcelona.

The actions studied by RELOCAL in Romania took place in the context of the big transformation that the country went through over the past three decades, i.e., the transformation of actually existing socialism into neoliberal

\footnotetext{
15 https://relocal.eu/wp-content/uploads/sites/8/2019/09/RELOCAL-National-Report_ Sweden.pdf

16 https://relocal.eu/wp-content/uploads/sites/8/2019/09/RELOCAL-National-Report_ Spain.pdf
} 
capitalism, which aggravated prior forms of unfairness and/or created new ones. Processes of privatization, marketization, formation of the banking sector, and the reduction of social expenditures were conditions for Romania's accession to the European Union and/or for gaining loans from international financial organizations. The author of the National Report ${ }^{17}$ observes that the competitive advantage of Romania on the stage of global capitalism is the low cost of its labor force, the country also being a market for imported products, and a territory opened for foreign capital investment. Regarding the territorial distribution of several socio-economic problems, statistical data shows that Romania has entered "the transition" with a relatively low level of regional disparities, compared to other new Member States, but that these disparities have increased rapidly. Territorial planning aims to back up the dominant developmental trends in the country, sustaining the model of polycentric development and agglomeration of economic activities in a few big cities. In this system, the socalled "magnet cities" are competing among each other to attract capital and to demonstrate their entrepreneurial capacities. The administrative-territorial organization of the country remained unchanged after 1990 in the sense that the localities and the counties continue to be the units where decisions are made by the elected deliberative bodies, but the whole system of public administration did undergo a process of decentralization. However, new forms of territorial governance that lack administrative/ political attributes have been formed to absorb EU funds. The four case studies conducted in Romania are highlighting several manifestations of spatial injustice, such as persistent residential segregation of the Roma, informal housing, declining rural areas in former mining territories, and underdevelopment of some urban areas in the capital city.

In all the cases mentioned above, the means of project-based interventions proved to be too weak in the face of the historically formed socio-economic inequalities, accumulated over time in particular territories, i.e., in spaces where economies and people suffered the most from the economic transformations of the past five decades of neoliberalism. Therefore, the actions (projects, strategies, programs) tackling manifestations of spatial injustice could make available more resources to more people during their life-time (filling a bit the deficits created as a result of the collapsing governmental redistribution systems, but as well as by economic congestions and lack of proper incomes); and/ or could create in the actions' participants a sense of increased procedural justice in what regards immediate community life, however ephemeral and formal that was in many cases. Nevertheless, they could not induce structural changes in either form of justice.

17 https://relocal.eu/wp-content/uploads/sites/8/2019/09/RELOCAL-National-Report_Romania.pdf 


\section{The formation of the competition union across changing regimes of capital accumulation and the lacking behind of social Europe}

Observing the creation of the "European communities" in the postwar history of capitalism, in this part of my analysis, I am going to refer to the following countries: Germany, France, the Netherlands, the United Kingdom, Finland, Sweden, Greece, Spain, Finland, Sweden, Poland, Hungary, and Romania. It will be briefly described when and from what positions they did enter into the process of EUfication as a manifestation of the phenomenon of the spatial fix. In parallel, the argument highlights how the EU's social dimension was always lagging as a non-imperative policy chapter and even more, how its neglect became stronger and stronger in time. The section concludes that these are explanatory factors of the persistence of unevenness in the competition union despite the EU's regional policy programs. ${ }^{18}$

\section{The creation of the first economic communities by the Western core: the era of state capitalism}

In 1951, the European Coal and Steel Community (ECSC) was founded by France, (West) Germany, Italy, the Netherlands, Belgium, and Luxembourg as the first of a series of supranational European institutions that aimed at the countries' economic unification. The initiative was inspired by Schuman's views (1950) on the advantages of such a "solidarity in production" or "productive unit" not only from the economic point of view of "the regions which have long been devoted to the manufacture of munitions of war", but also to "make it plain that any war between France and Germany becomes not merely unthinkable, but materially impossible" in the future.

In 1957, these six countries signed the Treaties of Rome, which marked the creation of the European Economic Community (EEC) and the European Atomic Energy Community (Euratom), and further, in the 1960s, they agreed to launch further common policies, i.e. on the domain of trade and agriculture. In 1973, the EEC expanded to nine Member States when Denmark, Ireland, and the United Kingdom joined the six initiators. The extended EEC introduced more common policies alongside the ones established at the beginning, in particular on social, environmental, and regional development issues.

\footnotetext{
18 Resources used for this reconstruction are available here - https://ec.europa.eu/regional_policy/en/policy/what/history/, here - https://ec.europa.eu/regional_policy/en/policy/what/ key-achievements/, and here - https://cohesiondata.ec.europa.eu/overview.
} 
As founding members, these countries had the advantage of defining the main frameworks of community policies, programs, and projects in a way that expressed their interests and the needs of their economies. Moreover, they were the countries that could impose the conditions on further candidate states, defining the directions of the economic reform that the latter was expected to go through, including among others the opening up of the borders to free trade and the so-called "sound public finances." As early as in the 1970s, the first leaders recognized that for the creation of a union not only the economic, fiscal and monetary policies need to be harmonized across countries, but also the disparities and differences between and within them, between industrial areas and agricultural regions, and as well as the challenges that declining industrial areas were faced with, had to be reduced. The importance of this objective was reckoned by the creation of the European Regional Development Fund in 1975.

In what regards the nation-state's policies during this period, they were framed by a particular regime of capital accumulation, i.e. state capitalism, based on the Keynesian welfare systems and economic policies. The latter put a great role on public investments among others into public services as a means for keeping economic production to work and as well as for assuring social peace and more balanced power relation between the owner classes and the working class. Altogether, I consider that this phase of the European political construction was based on two big pillars: social solidarity within the nationstates; and mutual support among the member states' national economies by ensuring that their businesses have unhindered access to a larger market than their national ones.

The European Single Market and the extension towards South and North: the first two decades of neoliberalization leading to the beginnings of fiscal surveillance

During the 1980s, the EEC was enlarged by the inclusion of some Mediterranean countries, such as Greece (in 1981), and Spain and Portugal (in 1986), after these countries having been emancipated from dictatorships. It was also this decade when the Single European Act was signed (in 1986). Viewing this decade from the angle of the capital accumulation regime, these were the years when neoliberal capitalism started to reshape national social and economic policies, and the role of the state in promoting privatization and marketization, and to facilitate the global circulation of capital in an unregulated manner. Programs such as Interreg, Leader, and Resider were conceived to better connect different regions, assure spatial mobility across Europe, and to revitalize declined rural, but as well as former industrial areas. 
Six years later, the member states defined the principles of the European Single Market - such as free trade, free movement of capital, people (including labor force), and services -, which made it possible to set up a business or take a job anywhere within the single market. These decisions were inscribed once and for all in the treaty that established later the European Union, i.e., the Maastricht Treaty activated in 1993, which also added further schemes of intergovernmental cooperation to the existing community system, in particular in the domain of foreign policy, justice, and internal affairs. The Committee of the Regions established in 1994 and the creation of the Cohesion Fund in the same year continued to ensure continuously the development of Europe's infrastructure through investments into environmental and transport-related objectives.

In 1995, Austria, Finland, and Sweden accessed the new EU, which - in the terms of regional policy - meant the addition of a special objective to support their sparsely-populated regions. Otherwise, the integration of the Structural Funds into an overarching cohesion policy aimed at adapting the economy of Greece, Spain, and Portugal to the European Single Market to both use them as new markets for Western European companies' products, and to create new jobs on their territories, and, generally speaking, in the poorest and most backward regions of the EU. Motorways, railway infrastructure, small and medium-sized companies, and, additionally, development goals in urban areas benefited from EU funds across all the Member States according to some regionally defined targets.

Meanwhile, a growing emphasis was put on increasing employment rates and people's employability. The latter concerns objectified in 1997 in the elaboration of the European Employment Strategy as defined in the Amsterdam Treaty. Despite being called a "social period" because compared to the Maastricht Treaty at least it delivered some promises on this domain, the era between 1997-2005 could not enforce more market correcting policies across the Union since all these happened in a context in which the EU did not push for legislative harmonization but, at the most, it aimed at a convergence towards best social policy practices (Pochet, 2020).

In parallel with the Amsterdam Treaty, the 27 Member States signed an agreement called the Stability and Growth Pact ${ }^{19}$ with the aim "to facilitate and maintain the stability of the Economic and Monetary Union." This agreement enabled the fiscal monitoring of members (their debts and deficits) by the

19 The Stability and Growth Pact was elaborated and it is still in use as a set of rules designed for the coordination of the economic and fiscal policies of the Member States, "ensuring that countries in the European Union pursue sound public finances and coordinate their fiscal policies." - https://ec.europa.eu/info/business-economy-euro/economic-and-fiscal-policy-coordination/ eu-economic-governance-monitoring-prevention-correction/stability-and-growth-pact_en. 
European Commission and the Council of Ministers, and the issuing of a yearly recommendation for policy actions. The Pact started to make effects via two resolutions: the regulation "on the strengthening of the surveillance of budgetary positions and the surveillance and coordination of economic policies" (1998); and the regulation "on speeding up and clarifying the implementation of the excessive deficit procedure" (1999).

From now on it became obvious, that it was not only the principle of free trade and free movement of capital that the Member States had to respect to secure the functioning of the Single Market but as well as keeping public deficits below $3 \%$ and public debt below $60 \%$ became compulsory policies on the benefit of the Monetary Union. The submission by the Member States of their National Reform Programs to be evaluated by the European Commission also turned into an obligatory mechanism. Last, but not least, it showed off undoubtfully that the European Union is primordially an economic union and its economic, fiscal, and monetary policies are enforced in all the Member States, while its promises of solidarity are promoted only via soft recommendations regarding national social policies.

\section{The integration of Eastern peripheries as new territories for capital investment: strengthening the competition union}

In March 2000, the EU heads of state and government launched the Lisbon Strategy, whose aim was to make Europe "the most competitive and dynamic knowledge-based economy in the world, capable of sustainable economic growth with more and better jobs and greater social cohesion." Central and East European countries, whose turn for accession to the EU came in the 2000s, went through the same destiny under the frame of Eastern enlargement like their South-European counterparts did two decades earlier. The "Copenhagen criteria" conditioned their accession by the existence of stable institutions guaranteeing democracy, by a functioning market economy endorsed by privatization, and the capacity to cope with competitive pressure and market forces within the Union, but as well as by the ability to take on the financial obligations of membership.

After the collapse of their socialist economies, Hungary, Poland, Czech Republic, Slovakia, Estonia, Latvia, Lithuania in 2004, respectively Romania and Bulgaria in 2007, and Croatia in 2013 were transformed into competitors at the peripheries for attracting foreign direct investment from core (European) countries. Especially Romania became the pole of the cheapest labor force from Europe, and - under conditions in which all of its internal production in all 
domains was destroyed - nowadays it functions as a market for imported goods, and as an emergent economy with low taxation on income, profit, and capital, but also as a country with natural resources to be exploited almost freely and without no strict environmental norms under very permissive state rules. After the full privatization and almost full bankruptcy of the economies of really existing socialism, it took a long period for CEE countries or for some of their urban regions to recover a bit. Their accession to the European Union meant that the latter's territorial disparities increased both in terms of economic and social indicators. Nevertheless, these so-called emergent economies are huge profit-making opportunities for foreign capital, a state of affairs facilitated and supported by the compulsory EU economic policies, while governmental social policy measures are limited by the obligatory fiscal policies leaving issues of poverty, exclusion, and marginalization on project-based interventions with no structural impact. Altogether, the case of the periphery or of the Southern and Eastern countries that were accessing later and in different waves the union, demonstrates that the cohesion policy aiming to reduce and eliminate economic, social, and territorial disparities cannot fulfill its objective until when the mainstream and compulsory economic policies favoring the maintenance of competition rule are recreating them.

The signing of the Lisbon Treaty at the end of 2007 (which was a solution to the failure of creating a stronger union on the base of a European Constitution) amended the neoliberal Maastricht Treaty. Redefining the competencies of the EU institutions also established the European Central Bank. Likewise, it reaffirmed that the services of general economic interest are to be provided by the national, regional, and local authorities. The Lisbon Treaty also re-enforced the neoliberal rule according to which the internal market of the Union has to include a system ensuring that competition is not distorted. Paradoxically or not, it entered into force in 2009, with the full outbreak of the financial crisis created by globalized capitalism obsessed with the imperative of permanent growth sustained by any means, among others by the means of growth based on private and public indebtedness.

The above trend was coupled by questioning altogether the importance of EU's social dimension: from the point of view of the EU social policymaking, between 2005-2014 the Barosso Commission led to the deterioration of the European Social Dialogue especially with the onset of the Eurozone crisis in 2009 (Tricart, 2020), and even the Open Method of Coordination on Social Protection and Social Inclusion lost its importance (Vanhercke, 2020). In parallel with this, the predominance of central-right and right-wing governments across the EU Member States favored anti-social austerity measures as a "solution" to the 
crisis and, altogether, the socio-economic governance of these times deepened the territorial inequalities in the EU and reinforced the tensions between social and economic policymaking.

\section{The Europe of austerity: recreating unevenness between the Western and Northern core, and the Southern and Eastern peripheries}

The Europe 2020 Strategy adopted in 2010 took further the neoliberal idea of competition for growth, nevertheless, it softened it with environmental and social concerns. It was set under the slogan of "smart, sustainable and inclusive growth." Yet, since its inception coincided with how the European Commission, the World Bank, and the International Monetary Fund (the Troika) thought to solve the 2008-2009 crisis (by saving the banks and imposing austerity measures on the population), the 2020 strategy put a great emphasis on macroeconomic and fiscal surveillance aiming at growth, employment creation and limitation of public spending. The third pillar of this strategy included all the rest of the themes that were supposed to be sustained by the relevant EU Funds, such as innovation and R\&D, resource-efficiency, business environment, employment, education, and social inclusion. Social inclusion and poverty eradication measures remained a competence within the Member States' sovereignty, while the control of deficit severely limited the countries' budgets allocated to social and public services. All these under conditions in which, as already shown, a huge difference continued to remain between the Members States' GDPs as a reference point for establishing the percentages of different types of governmental expenditures. The recommendations of the EC towards its Member States to reduce poverty and social exclusion or income inequalities were not taken seriously by the national decision-makers, while the compulsory economic measures continued to increase the severity of these problems. No wonder that the objectives of the EU strategies in this domain were never achieved, while disparities continued to be reproduced within and between the countries. Moreover, since the EU Funds, including those dedicated to combatting poverty and social exclusion, are supposed to be gained as a result of project competitions, the economically less competitive territories with their less entrepreneurial governments continue having fewer chances to attract such funds and acting locally against these problems created by trans-local forces.

As a result of the regulations written into the Maastricht, Amsterdam, and Lisbon Treaties conceived in a neoliberal spirit, the European Union was created as a competition union, or a union of states that compete with one another as if they were enterprises (Troost and Hersel, 2012). This union re-produced the 
inequalities between the export and surplus oriented core countries, and the periphery countries dependent to a considerable extent on imports and financed by external credit (Horn et al., 2009). In its turn, the competition union resulted in big imbalances, which manifested brutally after the 2008 financial crisis erupted and the austerity measures were enforced by the core countries (such as Germany) to be severely implemented in the periphery countries (such as Greece). Critics of neoliberal Europe named this type of integration as divisive integration (Lehndorff, 2015). Under this regime, the existing differences in terms of economic performance between the participating states could only increase, instead of diminishing.

Even if discursively the EU is constructed as space where the competition goes hand in hand with solidarity, and also with socio-economic and territorial cohesion, the actual construction of the Single Market shows: "in the rules, in accordance with which competition takes place, social standards do not have anything like the importance of the free movement of capital" (Lehndorff, 2015: 10). Furthermore, the economic EU governance based on surveillance, alongside fiscal austerity as a response to the debt crisis contradicted the inclusive growth paradigm and particularly its social component (Leschke et al., 2012). The neoliberal adjustment process as a way out of the crisis created even more critical issues. The post-financial crisis developments "rendered Italy and Spain even more vulnerable to the financial markets and made the exit of Greece, Portugal, and Ireland from the crisis even more difficult (Karamessini, 2012: 180). This diagnosis is also relevant for Central and Eastern European Member States. The dangers inherent to the austerity measures proved to be especially worrying for the countries that were by then in receipt of conditional financial assistance from the EU and the IMF (Greece, Portugal, Ireland, Latvia, and Romania) and already had poverty and social exclusion rates above the EU average, and lower levels of total social spending as a share of GDP.

The ongoing tensions within the EU socio-economic governance could not be solved either with the adoption of the European Pillar of Social Rights by the Juncker Commission in 2017. This was supposed to relaunch the social dimension of European integration, but this was impossible in the context of strengthening anti-European parties. Moreover, under conditions in which Business Europe refused negotiations on reopening the European Social Dialogue, at the most, the Pillar assessed the risk of lacking social Europe, but could not deliver concrete plans for really socializing EU policies, including the European Semester (Pocket, 2020). Nevertheless, in January 2020 the new von der Leyen Commission announced the need for a "strong social Europe for just transitions" including the transition to climate neutrality, digitalization, and proper policies to handle demographic change (Vanhercke et al., 2020). 
And here we are today at the end of 2020, fully facing a new crisis of capitalism (Roberts, 2020; Davis 2020). The economic recession already starting last year, continues to deepen as a consequence of the lockdown measures implemented to deal with Covid-19. In response, to save the economies, the European Commission suspended the strict state aid restrictions in mid-March 2020, allowing the $27 \mathrm{EU}$ states to pump cash into their economies and companies battered by coronavirus, with more than 1.9 trillion euros ( $\$ 2.1$ trillion) worth of national schemes approved so far. This is not an even game, however, as richer or less indebted states have more scope to channel funds. While Germany makes up about a quarter of the EU's gross domestic product (GDP), it accounts for some 52 percent of the total value of the emergency coronavirus state aid cleared so far, European Commission data show. "There is clearly a risk of a breakdown of ... the internal market in Europe," a senior Spanish government official said, since "not all the countries of the internal market have access to this liquidity ... Germany has deep pockets and can afford it." The European Commission's competition chief, Margrethe Vestager also recognized that "there are differences in how much member states can spend depending on their fiscal space." Facing these inequalities, again, South European countries demand joint EU financing to spur recovery, otherwise, they fear that not only will they have suffered more severely in the health crisis, but will also take longer to get their economies back on track. ${ }^{20}$

Under these recent conditions, in ETUI's Working Paper from June 2020, the authors wondered "whether the European Green Deal (EGD) constitutes a suitable policy framework to combine environmental and economic objectives with the pursuit of social fairness" (Sabato and Fronteddu, 2020, p.5). The question regarding the capacity of EGD to effectively act, beyond the discourse, as an overarching policy framework to ensure that the transition towards a more environmentally sustainable economic model is also socially fair continues to be relevant as the economic recession continues. This working paper warns that EGD's employability-related policies should not be considered as an alternative to universal social rights. Therefore, it states that EGD should adopt the provisions of the International Labor Organization's Just Transition Framework and the promises of the forgotten European Pillar of Social Rights, which lists a comprehensive number of social rights to be guaranteed to all European citizens and highlights the need to implement broader transition-related social policies with distributional effects.

20 State aid deepens concerns over EU divisions. Southern European nations fear their richer northern neighbors are undermining competition by bailing out industries, 2 May 2020, https://www.aljazeera.com/ajimpact/state-aid-deepens-concerns-eu-divisions200501171509547.html. 


\section{Conclusions}

Uneven development is an endemic feature of capitalism, both a product and a condition for the perpetuation of capital accumulation. On the one hand, it results from the fact that capital always looks for investing in new territories and domains where it might gain more profit. And, on the other hand, as a condition, uneven development facilitates that capitalism solves its inner crises by expanding towards underdeveloped territories with investment opportunities and cheap labor force. This is the process of spatial fix, which, in the case of EUfication functioned through the continuous enlargement of the "European communities". An official EU document (European Commission, 2016) explains this in the following terms: the European Union was created to achieve political goals through economic cooperation to ensure economic growth and be able to compete on the world stage with other major economies; decision-makers recognized that the European Single Market (created in 1986) could provide for the European companies a broader base than just their national home market; therefore, the EU endeavored to remove obstacles to trade (European Commission, 2016: 8). Further on, the facilitation of the free movement of capital by the Treaty on the European Union "was crucial for the evolutions of neoliberal global capitalism that needed new territories for capital investment, new markets for the surplus product as well as new sources of the cheap, both skilled and unskilled labor force" (Vincze, 2019:141). One of the conclusions of this article is that the position and timing from which and when different countries took part in the process of EUfication is a factor responsible for the persistence of uneven territorial development among the European core and periphery.

Unevenness persists despite the spatial policies inscribed in the European Spatial Planning Perspective (1999) and the Territorial Agenda 2020, which considered that the territorial approach is a key concept for harmonizing different development paradigms such as convergence (solidarity between regions) and regional competitiveness. This optimistic scenario is sustained even though the background documents of the EU's Territorial Agenda are acknowledging "the main territorial structures of Europe," which are: the core-periphery relations, the challenges of the East catching-up, the North-South differences, and the variety of rural-urban relations (The Territorial State and Perspectives in the European Union, 2011, p. 50-52). In describing them, this discourse uses concepts such as diversity, disparity, difference, distinctiveness, avoiding concepts such as inequality or injustice. The term "catching-up" is applied to suggest who is advanced and who is lagging from the listed couples of countries. There is no reference in this document to how capitalism creates such divisions, but the socialist heritage is mentioned as a factor that "slowed down the Central-Eastern 
European states." When talking about the disparities between the centrally located city regions and peripheral regions within the EU Member States, the document under our scrutiny uses the term polarization (idem, p. 53). Regarding the differences between areas within the urban settlements themselves, it even refers to inequalities, observing that, for example, "social differences between housing areas within a specific city are often bigger than between cities," which, assumedly, "influences negatively the attractiveness, competitiveness of cities" (idem, p.54). While reifying the competition between cities for investments (as a core element of entrepreneurial governance, described by Harvey, 1989; Hubbard and Hall 1998; Brenner and Theodore, 2002, 2005; Vincze, 2015), this understanding of the problem expects that improved collaboration and synergies among the settlements will put an end to polarization and inequalities. However, it is hard to believe that the entrepreneurial city will give up the perceived advantages of some capital investments for the benefit of other localities, with less capital on their doorstep. If competitiveness is expected to be the proper feature of different territories and this means making themselves attractive for capital or profit-making, one cannot imagine that solidarity claims will prevail over competition and competitiveness understood as the source of urban success in the ideology of market fundamentalism.

In my analysis, I have also reflected on the fact that even if the union defined itself as "a highly competitive social market economy, aiming at full employment and social progress," since neoliberal governance regulated the relations between the state, the market, and the society, "the tensions between market integration and social objectives continued to characterize the EU as territory" (Mulder, 2019) and the social policy paradigm was permanently overshadowed by market and financial considerations (Vanhercke et al., 2020).

Therefore, the second major conclusion of this article is that the predominance of economic policies over the social one has contributed to the perpetuation of uneven territorial development in the European Union. The way how social policies are conceived as soft recommendations to the Member States, cannot put an end to the unevenness created by the spatial fix looking for the interests of capital. The inequality-producing effects of the compulsory economic rules of the competition union are impossible to be eradicated by the means of recommendations that the EU makes on the behalf of social Europe, or by the seemingly politically neutral project-based interventions funded by EU financial schemes, which, at their turn, are also accessible only via competition mechanisms. The tensions between the market forces favoring the most competitive regions, i.e., those territories where investment for profit is the most promising, and between the social policies conceived to reduce poverty and inequalities, are deeply embedded into the functioning of the neoliberal 
union. The unevenness reproduced by the compulsory economic measures of the Single Market cannot be counteracted by the dismantled welfare regimes that outsourced the responsibility of solving the socio-economic and territorial unevenness to the competitive project-based initiatives.

Even more, as a very recent critical overview of the European social policies highlights, the program of Ursula von der Leyen reformulated the Europe 2020 Strategy's aim for a "smart, sustainable and inclusive growth" into a digital/smart, green/sustainable, and resilient deal. This shift is not so promising for a progressive social Europe, since while it is strongly focusing on economic sustainability it forgets about inclusiveness as core value, and, instead, it calls for resilience, i.e. for the preparation of the individuals "for adversity and shocks, without counting on the support of others" (Andor, 2020). Nowadays it becomes more and more clear that saving capitalist economy via state aids offered to private companies prevails over public investments into public services and over enforcing policies assuring universal socio-economic rights for all, most importantly to those who suffer the most from the effects of the current epidemiological and economic crisis.

\section{REFERENCES}

Barca, Fabrizio (2009) An Agenda for a Reformed Cohesion Policy. A place-based approach to meeting European Union challenges and expectations, https://ec.europa.eu/regional_policy/archive/policy/future/pdf/report_barca_ v0306.pdf

Behr, Harmut and Yannis A. Stivachtis, eds., (2016) Revisiting the European Union as Empire, London: Routledge.

Bofinger, Peter (2020) "The 'frugal four' should save the European project," Social Europe, 4th of May 2020, https://www.socialeurope.eu/the-frugal-four-shouldsave-the-european- project

Böröcz, József and Kovács Mária, eds., (2001) Empires New Clothes. Unveiling EU Enlargement, Central Europe Review.

Branner, Neil and Nik Theodore (2005) "Neoliberalism and the Urban Condition," City, 9(1):101-107, DOI: 10.1080/13604810500092106.

Brenner, Neil and Nik Theodore, eds., (2002) Spaces of Neoliberalism: Urban Restructuring in North America and Western Europe, Oxford: Blackwell.

Consolidated Version of the European Union Treaty (2012) Official Journal of the European Union, https://eur-lex.europa.eu/resource.html?uri=cellar:2bf140bfa3f8-4ab2-b506- qfd71826e6da6.0023.02/DOC_1\&format=PDF

Davis, Mike (2020) "The Coronavirus Crisis Is a Monster Fueled by Capitalism," In The Times, https://inthesetimes.com/article/22394/coronavirus-crisis-capitalismcovid-19-monster-mike-davis 
European Commission (1999) European Spatial Planning Perspective. Towards Balanced and Sustainable Development of the Territory of the European Union, https://ec.europa.eu/regional_policy/sources/docoffic/official/reports/ pdf/sum_en.pdf

European Commission (2008) Communication from the Commission to the Council, the European Parliament, the Committee of the Regions, and the European Social and Economic Committee. Green Paper on Territorial Cohesion, https://eur-lex.europa.eu/LexUriServ/LexUriServ.do?uri=COM:2008: 0616:FIN:EN:PDF

European Commission (2010) Europe 2020: A strategy for smart, sustainable and inclusive growth, http://eur-lex.europa.eu/LexUriServ/LexUriServ.do?uri=COM: 2010:2020:FIN:EN:PDF

European Commission (2016) Europe in 12 lessons, https://op.europa.eu/en/publication-detail/-/publication/a5ba73c6-3c6a-11e8b5fe-01aa75ed71a1

Harvey, David (1989) "From Managerialism to Entrepreneurialism: The Transformation in Urban Governance in Late Capitalism," Geografiska Annaler, Series B, Human Geography, Vol. 71, No. 1: 3-17.

Harvey, David (2001) "Globalization and the spatial fix", Geographische Revue, 2, 23-30, https://publishup.uni-potsdam.de/opus4-ubp/frontdoor/deliver/index/docId/ 2251/file/gr2_01_Ess02.pdf

Harvey, David. 2005. Spaces of neoliberalization: towards a theory of uneven geographical development, F.S. Verlag.

Harvey, David (2006) Spaces of Global Capitalism: A Theory of Uneven Geographical Development, London: Verso.

Horn, Gustav, Katharina Dröge, Simon Sturn, Till van Treeck, and Rudolf Zwiener (2009) Von der Finanz- krise zur Weltwirtschaftskrise (III): Die Rolle der Ungleichheit, IMK Report 41, Düsseldorf, Institut für Makroökonomie und Konjunkturforschung.

Jessop, Bob (2001) "Spatial Fixes, Temporal Fixes, and Spatio-Temporal Fixes," published by the Department of Sociology, Lancaster University, United Kingdom, https://www.lancaster.ac.uk/fass/resources/sociology-online-papers/papers/ jessop-spatio-temporal-fixes.pdf

Karamessini, Maria (2019) "Sovereign debt crisis: an opportunity to complete the neoliberal project and dismantle the Greek employment model," in Steffen Lehndorff (ed): A triumph of failed ideas. European models of capitalism in the crisis, European Trade Union Institute, pp.155-183

Lang, Tholo and Franziska Görmar, eds., (2019) Regional and Local Development in Times of Polarisation. Re-thinking Spatial Policies in Europe, Palgrave Macmillan.

László, Andor (2020) "Europe 2020", Progressive Posts, https://progressivepost.eu/spotlights/ europe-in-2020

Lehndorff Steffen, ed., (2015) Divisive integration. The triumph of failed ideas in Europe revisited, European Trade Union Institute. 
Leschke, Janine, Sotiria Theodoropoulou and Andrew Watt (2012) "How do economic governance reforms and austerity measures affect inclusive growth as formulated in the Europe 2020 Strategy," in Steffen Lehndorff (ed.): A triumph of failed ideas. European models of capitalism in the crisis, European Trade Union Institute, pp. 243-283

Marlier, Eric, David Natali and Rudi van Dam, eds., (2010) Europe 2020. Towards a More Social EU?, P.I.E. Peter Lang, 2010

Medeiros, Eduard (2016) “Territorial Cohesion: An EU Concept," European Journal of Spatial Development, No. 60, https://archive.nordregio.se/Global/EJSD/Refereed\%20articles/ refereed60.pdf

Mulder, Jotte (2019) "(Re) Conceptualising a Social Market Economy for the EU Internal Market," Utrecht Law Review, 15(2): 16-31, DOI: http://doi.org/10.18352/ulr.508, https://www.utrechtlawreview.org/articles/10.18352/ulr.508/

Pocket, Philippe (2020) "Twenty years of the publication 'Social policy in the European Union': what have we learned?", in Bart Vanhercke, Dalila Ghailani, Slavina Spasova, Philippe Pocket (eds): Social policy in the European Union 1999-2019: the long and winding road, European Trade Union Institute (ETUI), European Social Observatory (OSE), Brussels, pp.13-34.

Roberts, Michael (2020) It was the virus that did it, Michael Roberts Blog, https://thenextrecession.wordpress.com/2020/03/15/it-was-the-virus-that-did-it

Sabato, Sebastiano and Boris Fronteddu (2020) A socially just transition through the European Green Deal?, Working Paper, European Trade Union Institute.

Schmidt, Ingo (2018) "Neoliberal capitalism and its crises in Europe: towards a Luxemburgian interpretation," New Formations, 94: 100-120.

Schuman Declaration - 9th of May 1950, https://europa.eu/european-union/abouteu/symbols/europe-day/schuman-declaration_en

Shore, Cris and Susan Wright, eds., (1997) Anthropology of Policy: critical perspectives on governance and power, Routledge.

Shore, Cris, Susan Wright and Davide Pero, eds., (2011) Policy worlds. Anthropology and the Analysis of Contemporary Power, Berghahn.

Smith, Neil (1984) Uneven Development: Nature, Capital, and the Production of Space, Blackwell.

The Territorial State and Perspectives in the European Union. 2011 update. Background document for the Territorial Agenda of the European Union 2020, https://ec.europa.eu/regional_policy/sources/policy/what/territorial-cohesion/ territorial_state_and_perspective_2011.pdf

The Treaty of Lisbon, https://www.europarl.europa.eu/factsheets/en/sheet/5/thetreaty-of-lisbon

Tricot, Jean-Paul (2020) "Once upon a time there was the European social dialogue", in Bart Vanhercke, Dalila Ghailani, Slavina Spasova, Philippe Pochet (eds.): Social policy in the European Union 1999-2019: the long and winding road, European Trade Union Institute (ETUI), European Social Observatory (OSE), Brussels, pp.7199. 
Troost A. And Hersel P. (2012) Die Euro-Krise als Zäsur: Eine neue Finanz-, Geld-, und Wirtschaftspolitik in Europa, Luxemburg, Gesellschaftsanalyse und linke Praxis, http://www.zeitschrift-luxemburg.de/?p=2082

Vanhercke, Bart, Slavina Spasova, Dalila Ghailani and Philippe Pochet (2020) "Preface", and "Conclusions: the twists and turns of two decades of EU social policymaking", in Bart Vanhercke, Dalila Ghailani, Slavina Spasova, Philippe Pochet (eds.): Social policy in the European Union 1999-2019: the long and winding road, European Trade Union Institute and European Social Observatory, Brussels, pp. 9-13, and pp. 183-203.

Vanhercke, Bert, Dalila Ghailani, Slavina Spasova and Philippe Pochet, eds., (2020) Social policy in the European Union 1999-2019: the long and winding road, European Trade Union Institute and European Social Observatory, Brussels.

Vincze, Enikő (2015) "Glocalization of neoliberalism in Romania. Through the reform of the state and entrepreneurial development," Studia Universitatis Babes-Bolyai Europaea, Volume 60: Issue 1: 125-152.

Vincze, Enikő (2019) "Three decades after. Advancing capitalism and the (re)production of Romania's semi-peripherality," Studia Universitatis Babes-Bolyai Sociologia, Volume 64: Issue 2: 141-164, DOI: https://doi.org/10.2478/subbs-2019-0013.

Zielonka, Jan (2006) Europe as Empire. The Nature of the Enlarged European Union, Oxford University Press. 